\title{
Accumulation and Depuration of Yessotoxin in Two Bivalves
}

Author(s): Karin Röder, Nicole Fritz, Gunnar Gerdts and Bernd Luckas

Source: Journal of Shellfish Research, 30(1):167-175. 2011.

Published By: National Shellfisheries Association

DOI: $10.2983 / 035.030 .0124$

URL: http://www.bioone.org/doi/full/10.2983/035.030.0124

BioOne (www.bioone.org) is an electronic aggregator of bioscience research content, and the online home to over 160 journals and books published by not-for-profit societies, associations, museums, institutions, and presses.

Your use of this PDF, the BioOne Web site, and all posted and associated content indicates your acceptance of BioOne's Terms of Use, available at www.bioone.org/page/terms_of_use.

Usage of BioOne content is strictly limited to personal, educational, and non-commercial use. Commercial inquiries or rights and permissions requests should be directed to the individual publisher as copyright holder. 


\title{
ACCUMULATION AND DEPURATION OF YESSOTOXIN IN TWO BIVALVES
}

\author{
KARIN RÖDER, ${ }^{1, *}$ NICOLE FRITZ, ${ }^{1}$ GUNNAR GERDTS ${ }^{2}$ AND BERND LUCKAS ${ }^{1}$ \\ ${ }^{1}$ Institute of Nutrition, Friedrich-Schiller-University of Jena, Dornburger Straße 25, D-07743 Jena, \\ Germany; ${ }^{2}$ Biologische Anstalt Helgoland, Alfred-Wegener-Institute for Polar and Marine Research, \\ PO Box 180, 27498 Helgoland, Germany
}

\begin{abstract}
Contamination of bivalves with yessotoxins (YTXs) has been reported since 1987 in several coastal environments. In our study we investigated the accumulation and the metabolism of YTXs in 2 bivalve species important to German fisheries and aquaculture. Mussels and oysters, Mytilus edulis and Crassostrea gigas, were exposed to the YTX-producing dinoflagellate Protoceratium reticulatum isolated from the North Sea. Toxin profiles from algae and bivalves were analyzed by liquid chromatography with tandem mass spectrometry (LC-MS/MS). It was evident that 45-hydroxy YTX (45-OH YTX), carboxy YTX (COOH YTX), and the putative 45-hydroxy-carboxy YTX (45-OH-COOH YTX) were the dominant YTX analogues in $M$. edulis. The oyster $C$. gigas displayed a different toxin profile. YTX, 45-OH YTX, and 45-OH-COOH YTX were also present, but $\mathrm{COOH}$ YTX was not detectable. Furthermore, 2 unidentified analogues with the same MS/MS transition ([M-H $\left.]^{-}>\left[\mathrm{M}-\mathrm{H}-\mathrm{SO}_{3}\right]^{-}\right)$ occurred in both bivalve species. Homo YTX and 45-hydroxy-homo YTX, which are regulated together with YTX and 45-OH YTX in 2002/225 EC were not detected. In general, we confirmed former field investigations on accumulation and metabolism of YTXs in M. edulis; however, this is the first study on accumulation and metabolism of YTXs in the oyster C. gigas.
\end{abstract}

KEY WORDS: marine toxins, shellfish toxicity, yessotoxin, YTX, 45-hydroxy yessotoxin, carboxy yessotoxin, keto yessotoxin, Protoceratium reticulatum, Gonyaulax grindleyi, blue mussels, Mytilus edulis, Pacific oysters, Crassostrea gigas, LC-MS/MS, metabolism

\section{INTRODUCTION}

Yessotoxin (YTX), a disulfated polyether toxin was first isolated by Murata et al. (1987) from the digestive glands of Japanese scallops (Patinopecten yessoensis). To the present, YTX has been detected in phytoplankton and shellfish from New Zealand (MacKenzie et al. 1998), Japan (Suzuki et al. 2007), Italy (Ciminiello et al. 1997, Ciminiello et al. 2003), Chile (Yasumoto \& Takizawa 1997), Norway (Aasen et al. 2005), Canada (Paz et al. 2008), the United States (Paz et al. 2007), Spain (Paz et al. 2004, Paz et al. 2007), and Africa (Krock et al. 2006).

Three species of dinoflagellates have been identified as causative organisms: Protoceratium reticulatum (Claparede \& Lachmann) Buetschli (=Gonyaulax grindleyi) (Satake et al. 1997), Lingulodinium polyedrum (Stein) Dodge (=Gonyaulax polyedra) (Tubaro et al. 1998, Draisci et al. 1999), and Gonyaulax spinifera (Claparede \& Lachmann) Diesing (Rhodes et al. 2006, Riccardi et al. 2009). Meanwhile, the production of YTX by the dinoflagellate $P$. reticulatum has been reported in New Zealand (Satake et al. 1997), Japan (Satake et al. 1999), Norway (Ramstad et al. 2001, Samdal et al. 2004), and Africa (Krock et al. 2006).

Many different YTX analogues were detected until now, but of about 100 YTXs, only $40 \%$ are characterized concerning their exact chemical structure (Paz et al. 2008). The best known modifications at the YTX backbone are insertion of a methyl group between C-1 and C-2 (e.g., 1a-homo YTX) as well as between C-41 and C-42 (e.g., 41a-homo YTX), methylation of C-9 (e.g., 9-Me-41a homo YTX), glycosylation of C-32 (e.g., glyco YTX A), several modifications at the unsaturated side chain (e.g., carboxylation (COOH YTX), hydroxylation (45OH YTX, 44,55-di OH YTX), addition of amides (e.g., trihydroxylated amide of 41a-homo YTX), elimination of different parts (e.g., trinor YTX, keto YTX, ketohomo YTX), absence of ring A (e.g., nor-ring A YTX), desulfonations (e.g.,

*Corresponding author. E-mail: Karin.Roeder@uni-jena.de DOI: $10.2983 / 035.030 .0124$ 1-ds YTX, 4-ds YTX), and many variations of the aforementioned (Miles et al. 2004, Finch et al. 2005, Miles et al. 2005a, Miles et al. 2005b, Souto et al. 2005, Miles et al. 2006a, Miles et al. 2006b, Ciminiello et al. 2007). Beside these structural variations, another YTX-like toxin (adriatoxin; ATX) was isolated from mussels of the Adriatic Sea. The structure of ATX is similar to YTX for ring A-ring $\mathrm{J}$ but, in contrast, the $11^{\text {th }}$ ether ring (ring $\mathrm{K}$ ) is absent. In addition, ATX contains a hydroxyl group at C-36 and a 3rd sulfate group at C-37 at ring J (Ciminiello et al. 1998).

YTX is mainly produced by $P$. reticulatum, albeit some strains have been found with homo YTX as the prominent analogue (Paz et al. 2008). The different YTXs are produced by dinoflagellates to a considerable extent (Suzuki et al. 2007); however, some of them are metabolized in the shellfish tissue (Miles et al. 2004).

The chemical structure of YTX is closely related to other ladder-shaped polyethers like ciguatoxin (CTXs), maitotoxin, brevetoxins (PbTXs), and some diarrhetic shellfish toxins (DSTs). CTXs and (PbTXs) are potent activators of voltagegated sodium channels in mammals (Dechraoui et al. 1999, Denac et al. 2000, Naar et al. 2007). In contrast, YTX neither causes an activation of this type of ion channels (Inoue et al. 2003) nor inhibits protein phosphatases 1 and $2 \mathrm{~A}$, which is typical for okadaic acid and dinophysistoxin-1 (Takai \& Mieskes 1991, Takai et al. 1992, Honkanen et al. 1994, Windust et al. 1996). In addition, YTX does not cause fluid accumulation and it is not hemolytic or ichthyotoxic (Ogino et al. 1997). Nevertheless, YTXs are potent cytotoxins (Paz et al. 2008), able to cause damage of the myocardium (Aune et al. 2002, Tubaro et al. 2004). Furthermore, YTX affects $\mathrm{Ca}^{2+}$ influx in human lymphocytes (De la Rosa et al. 2001), produces a $\mathrm{Ca}^{2+}$-dependent decrease of cyclic adenosine monophosphate (Alfonso et al. 2003, Pazos et al. 2005), slows down the disposal of an E-cadherine degradation product $\left(\right.$ ECRA $\left._{100}\right)$ (Callegari \& Rossini 2008), and causes neurotoxicity in rat cerebellar neurons (Pérez-Gómez et al. 2006). 
Referring to the classic mouse bioassay, YTX was classified into the group of DSTs. However, Satake et al. (1999) discovered that YTX given per os does not cause symptoms comparable with other DSTs. As a result of these findings, YTX and its analogues were separated from other DSTs into their own toxin category by the scientific community.

In 2002 the European Commission decided that the limit of YTX and its analogues has to be set up to $1 \mathrm{mg} / \mathrm{kg}$ of shellfish meat (European Commission 2002). It was considered, that this threshold is valid for YTX and 3 of its analogues: 45-hydroxyYTX (OH YTX), 1a-homo YTX (homo YTX), and 45-hydroxyla-homoYTX (OH-homo YTX). Furthermore, some countries established toxic equivalence factors for these YTXs (YTX $=1$, homo $\mathrm{YTX}=1$, OH YTX $=1$, and OH-homo YTX $=0.5$ (European Food Safety Authority 2008). Recently, the European Food Safety Authority published that a 400-g portion of shellfish meat should not contain more than $3.75 \mathrm{mg}$ YTX eq/ $\mathrm{kg}$, a concentration higher than that of the current regulation limit (European Food Safety Authority 2008).

Independent of the problem of regulation of upper limits for YTXs in seafood, there is still a lack of information about the metabolism of YTXs in shellfish. Aasen et al. (2005), Ciminiello et al. (2000), and MacKenzie et al. (2002) reported an accumulation of YTXs in mussels after blooms of $P$. reticulatum. The results indicated that the accumulation, metabolism, and depuration of YTXs depend directly on the toxin composition of the bloom-forming dinoflagellates. In this context, temperature and food availability are additional factors that influence the depuration of shellfish contaminated with YTXs (Blanco et al. 1999).

The aim of this study was to elucidate the accumulation and depuration of YTXs in Mytilus edulis and Crassostrea gigas of the North Sea, which are important for German fishery and shellfish industries. Furthermore, we wished to clarify the possible metabolic pathway of YTX in different shellfish species.

\section{MATERIALS AND METHODS}

\section{Experimental Protocol and Sample Extractions}

\section{P. reticulatum Cultures}

The dinoflagellate $P$. reticulatum used for the experiments was isolated by M. Hoppenrath from the North Sea. Several cultures were grown sequentially in $\mathrm{f} / 2$ medium without silica (Guillard 1975) at $60-90 \mu \mathrm{mol} / \mathrm{sec} / \mathrm{m}^{2}$ and $14^{\circ} \mathrm{C}$, using a $14-\mathrm{h} /$ 10-h light/dark regime in 10-L borosilicate flasks. After 21 days, the cultures reached the mid exponential growth phase, and $2 \mathrm{~L}$ of the culture was withdrawn for inoculating each bivalve tank. In addition, $90 \mathrm{~mL}$ was filtered on $\mathrm{GF} / \mathrm{C}$ filters (Whatman, Great Britain) for toxin analysis and $10 \mathrm{~mL}$ was used to determine cell densities. For determination of the cell density, cells were fixed in Lugol's iodine solution (Carl Roth GmbH \& Co, Germany) and counted using Sedgwick rafter's counting chamber under light microscopy (10× magnification); a minimum 400 cells were counted.

\section{Bivalves and Experimental Conditions}

Mussels, M. edulis, were collected from Helgoland Roads in the North Sea by scuba diving. Oysters, C. gigas, were collected from the tidal zone of the island Sylt (Germany). The toxification of the bivalves with $P$. reticulatum was carried out in tanks filled with $25 \mathrm{~L}$ natural seawater, and $2 \times 24$ samples per species were placed in separate tanks. Because of the smaller size, we pooled 6 individuals of $M$. edulis and handled them in our analyses as 1 sample.

Bivalves with similar sizes were selected and the size was recorded (M. edulis: length, $5.9 \pm 0.7 \mathrm{~cm}$; width, $2.8 \pm 0.4 \mathrm{~cm} ; C$. gigas: length, $8.6 \pm 1.2 \mathrm{~cm}$; width, $6.4 \pm 1.2 \mathrm{~cm}$ ). To ensure constant water conditions, oxygen content and temperature were measured over the entire project (OxyScan Graphic; Umwelt-, Membran- und Sensortechnik Melningen; Germany). The oxygen concentration was $8 \pm 0.3 \mathrm{mg} / \mathrm{L}$ (saturation, $95 \pm 1.4$ $\%)$ and the water temperature was $18 \pm 0.5^{\circ} \mathrm{C}$.

The experiment was subdivided into 3 parts, the toxification period (16 days), a break (4 days), and the detoxification period (16 days). The break was inserted because earlier experiments showed that mussels need time for depuration. The sampling was carried out during toxification $(n=2)$ and detoxification $(n=1)$ every 2 nd day. The tanks were cleaned, supplied with new seawater, and filled with bivalves to the prior amount. We fed $2 \mathrm{~L}$ of the midexponential algal culture, containing 7,000 cells/mL on average, per tank $(25 \mathrm{~L})$ during the toxification period. Hence, the total concentration in the tank was approximately 520 cells $/ \mathrm{mL}$. During the break and detoxification periods, bivalves were fed with natural plankton from the North Sea. Bivalve samples were lyophilized and stored in the freezer at $-20^{\circ} \mathrm{C}$ until extraction.

\section{Extraction of Yessotoxins}

Lyophilized filters of $P$. reticulatum were extracted with methanol $(\mathrm{MeOH})$ using an ultrasonic bath for $15 \mathrm{~min}$ and centrifuged at $14,000 \mathrm{~g}$ for $10 \mathrm{~min}$. Extracts were placed in 2$\mathrm{mL}$ single-use syringes and filtered through a $0.45-\mu \mathrm{m}$ nylon filter (Carl Roth GmbH \& Co., Germany). They were stored at $-20^{\circ} \mathrm{C}$ in a brown autosampler vial until analyses by HPLC$\mathrm{MS} / \mathrm{MS}$.

For the extraction of the bivalve samples, lyophilized material was ground using a mortar. After determination of dry weight, $30 \mathrm{~mL} \mathrm{MeOH}$ was added to M. edulis and $20 \mathrm{~mL} \mathrm{MeOH}$ was added to $C$. gigas. The samples were vortexed for $1 \mathrm{~min}$ and subsequently extracted using a cooled ultrasonic bath for $15 \mathrm{~min}$. To guarantee a good recovery, we allowed soaking overnight and extracted them again using an ultrasonic bath (15 min). The extracts were centrifuged at $12,000 \mathrm{~g}$ for $45 \mathrm{~min}$ (Sorvall RC-5B Superspeed Centrifuge, Du Pont Instruments). The supernatant was evaporated to dryness under nitrogen and resolved in $3 \mathrm{~mL}$ $\mathrm{MeOH}$ by vortexing again for $1 \mathrm{~min}$, and afterward centrifuged for $10 \mathrm{~min}$ at 4,500 (CR-412 refrigerated centrifuge; Jouan). Finally, extracts were filtered through $0.45-\mu \mathrm{m}$ nylon filters (Carl Roth $\mathrm{GmbH} \& \mathrm{Co}$.) and stored at $-20^{\circ} \mathrm{C}$ until analysis by LC$\mathrm{MS} / \mathrm{MS}$ in brown autosampler vials.

\section{LC-MS/MS Analysis}

Certified YTX standard solution dissolved in $\mathrm{MeOH}$ was obtained from the National Research Council Canada. HPLC was carried out with 2 LC-10 AT pumps, a SIL-10 AD VP autosampler, an SCL-10 AT VP controller, and a CTO-10 AS VP column oven (Shimadzu GmbH, Germany). Liquid chromatography was performed using a Hyperclone C8 column ( $3 \mu \mathrm{m}, 130$ 
$\AA$ A $50 \times 2.0 \mathrm{~mm}$ ) with security guard (Phenomenex, Germany) by gradient elution at a flow of $0.3 \mathrm{~mL} / \mathrm{min}$. The injection volume was $10 \mu \mathrm{L}$. The mobile phase consisted of eluent A $(5 \mathrm{mM}$ ammonium formate in acetonitrile/water (10:90)) and eluent B (5 mM ammonium formate in acetonitrile/water (90:10)). The gradient elution was done with $100 \%$ A for $1.5 \mathrm{~min}$, followed by linear gradient to $40 \%$ A over $3.5 \mathrm{~min}$, held over $5.0 \mathrm{~min}$, and within $1.0 \mathrm{~min}$ to $100 \% \mathrm{~B}$, held for $9.0 \mathrm{~min}$ and at least within $1.0 \mathrm{~min}$ back to $100 \% \mathrm{~A}$, held for $24 \mathrm{~min}$.

MS/MS analyses were performed using a Triple Quadrupole API 365 LC-MS/MS (Applied Biosystems GmbH, Germany) with electrospray ionization by ESI Turbo Ion spray Interface (SCIEX, Canada). The following parameters were used: nebulizer gas, $13 \mathrm{~L} / \mathrm{min}$; curtain gas, $12 \mathrm{~L} / \mathrm{min}$; ion spray voltage, $-4,500 \mathrm{~V}$; desolvation temperature, $450^{\circ} \mathrm{C}$; collisionally activated dissociation gas, $8 \mathrm{~L} / \mathrm{min}$; declustering potential, $-12 \mathrm{~V}$; focusing potential, $-180 \mathrm{~V}$; entrance potential, $-8 \mathrm{~V}$; collision energy, $-45 \mathrm{~V}$; and collision cell exit potential, $-51 \mathrm{~V}$.

After several scans in the Q1 (stepwise from 500-1,800 amu) and measurements in the single ion monitoring mode, neutral loss mode (loss of $80 \mathrm{amu}\left[\mathrm{SO}_{3}\right]$ ), and product ion mode (parent ion: $m / z 1,141.5$, scan for fragments $m / z$ 500-1,200), qualitative analyses were carried out in multireaction monitoring mode with negative ionization. Selected transitions were (precursor ion $[\mathrm{M}-\mathrm{H}]^{-}>$fragment ion $\left.\left[\mathrm{M}-\mathrm{H}-\mathrm{SO}_{3}\right]^{-}\right)$: YTX $m / z$ 1,141.5 > 1,061.5, homo YTX $m / z 1,155.5>1,075.5,45-\mathrm{OH}$ YXT $m / z$
$1,157.5>1,077.5$, COOH YTX $m / z 1,173.5>1,093.5$, the putative 45-OH COOH YTX $m / z 1,189.8>1,109.5, m / z$ $1,047.5>967.5$ (probably keto YTX), and $m / z 1,191.5>1,111.5$.

The YTX content was estimated using a 3-point calibration curve. It was determined with certified YTX standard solution (National Research Council Canada). Because of the lack of standard solutions for the YTX analogues it was not possible to calculate the absolute amount of YTXs in the shellfish samples. Hence, the LC-MS/MS results for YTXs were calculated with reference to the YTX standard solution. The limit of detection using a signal-to-noise ratio of 3:1 was $0.02 \mathrm{ng}$ YTX on column. As a result of eventual variations in sensitivity for the different YTXs by LC-MS/MS, it was not possible to calculate the amounts of YTXs with the molecular weight (MW) of the metabolites. Therefore, the concentrations were expressed as YTX equivalents.

\section{RESULTS}

\section{Toxins in P. reticulatum Cultures}

YTX (MW, 1,142 Da) was detected in P. reticulatum by application of LC-MS/MS, whereby the cells contained $5.58 \pm$ $1.66 \mathrm{pg}$ YTX/cell $(n=6)$. Traces $(<0.3 \mathrm{pg}$ YTX eq/cell) of $\mathrm{COOH}$ YTX and the putative keto YTX were also found. The total amount of YTX, $605.97 \mu \mathrm{g}$ YTX/tank, fed over the entire
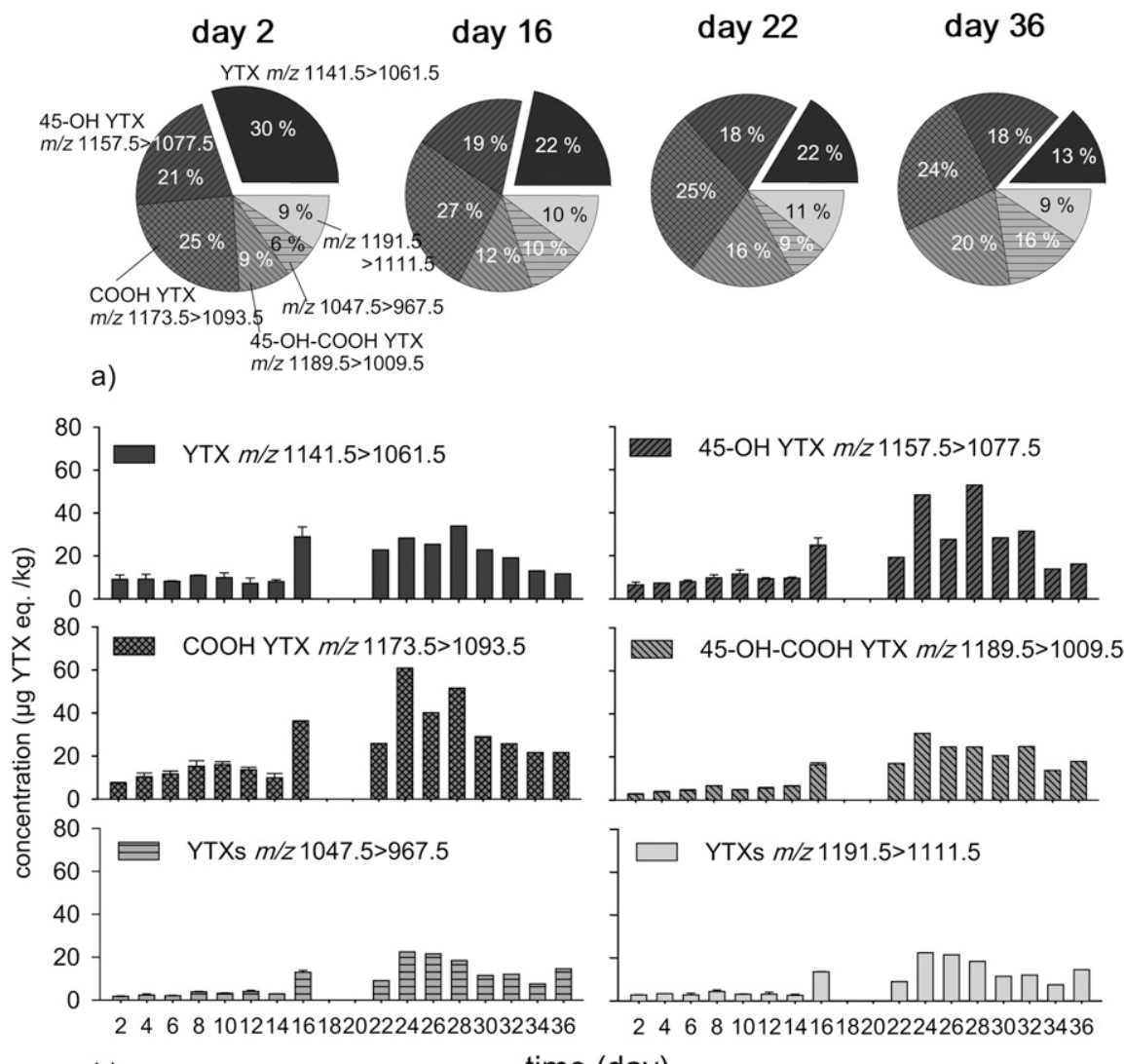

b)

time (day)

Figure 1. (A, B) Concentration of YTXs in M. edulis as percentage (A) and as a total concentration in micrograms YTX equivalents per kilogram wet weight (B). Analogues in YTX equivalents (YTX Rt, 21.3 min; 45-OH-YTX Rt, 19.4 min; COOH YTX Rt, 18.5 min; 45-OH-COOH YTX Rt, 18.7; m/z $1,147.5>967.5$ with an Rt of $19.5 \mathrm{~min}$ and $m / z 1,147.5>967.5$ with an Rt of $18.2 \mathrm{~min})$. 
TABLE 1.

Concentration of YTXs in M. edulis in microgram YTX equivalents per kilogram wet weight.

\begin{tabular}{|c|c|c|c|c|c|c|}
\hline Transition & $\begin{array}{c}m / z 1,141.5> \\
1,061.5\end{array}$ & $\begin{array}{c}m / z 1,157.5> \\
1,077.5\end{array}$ & $\begin{array}{c}m / z 1,173.5> \\
1,093.5\end{array}$ & $\begin{array}{c}m / z 1,189.5> \\
1,089.5\end{array}$ & $\begin{array}{c}m / z 1,047.5> \\
967.5\end{array}$ & $\begin{array}{c}m / z, 1,191.5> \\
1,111.5\end{array}$ \\
\hline Retention time (min) & 21.3 & 19.4 & 18.5 & 18.7 & 19.5 & 18.2 \\
\hline Time (day) & \multicolumn{6}{|c|}{ concentration $(\mu \mathrm{g} / \mathrm{kg} \mathrm{BW})$} \\
\hline 2 & 9.12 & 6.50 & 7.42 & 2.66 & 1.77 & 2.81 \\
\hline 4 & 9.18 & 7.30 & 10.44 & 3.69 & 2.35 & 3.35 \\
\hline 6 & 8.14 & 8.01 & 11.69 & 4.44 & 2.03 & 2.83 \\
\hline 8 & 10.95 & 9.73 & 15.24 & 6.54 & 3.89 & 4.42 \\
\hline 10 & 9.89 & 11.50 & 16.18 & 4.74 & 3.20 & 3.09 \\
\hline 12 & 7.20 & 9.38 & 13.61 & 5.55 & 4.07 & 3.15 \\
\hline 14 & 8.03 & 9.64 & 9.91 & 6.43 & 2.88 & 2.63 \\
\hline 16 & 28.92 & 24.98 & 36.29 & 16.50 & 12.93 & 13.63 \\
\hline 22 & 22.84 & 19.24 & 25.88 & 17.01 & 9.06 & 11.45 \\
\hline 24 & 28.35 & 48.27 & 60.84 & 30.98 & 22.51 & 14.17 \\
\hline 26 & 25.40 & 27.63 & 40.17 & 24.64 & 21.50 & 14.63 \\
\hline 28 & 33.93 & 57.86 & 51.55 & 24.57 & 18.42 & 11.20 \\
\hline 30 & 22.86 & 28.38 & 29.07 & 20.60 & 11.51 & 7.95 \\
\hline 32 & 19.14 & 31.42 & 25.74 & 24.86 & 12.04 & 13.09 \\
\hline 34 & 13.06 & 13.85 & 21.68 & 13.75 & 7.57 & 7.78 \\
\hline 36 & 11.67 & 16.18 & 21.64 & 17.89 & 14.58 & 7.98 \\
\hline
\end{tabular}

toxification period, was calculated on the basis of cell densities and YTX load per cell.

Toxins in Bivalves: Accumulation, Metabolism, and Depuration

M. edulis contained YTX, 45-OH YTX, COOH YTX, and the putative 45-OH COOH YTX. The retention times (Rt) of the detected YTXs were YTX $m / z 1,141.5>1,061.5$ with an Rt of $21.3 \mathrm{~min}, 45-\mathrm{OH}$ YTX $m / z 1,157.5>1,077.5$ with an Rt of
19.4 min, COOH YTX $m / z 1,173.5>1,093.5$ with an Rt of 18.2 min, and 45-OH-COOH YTX $m / z 1,189.8>1,109.5$ with an Rt of $18.7 \mathrm{~min}, m / z 1,047.5>967.5$ with an Rt of $19.5 \mathrm{~min}$, and $m / z$ $1,191.5>1,111.5$ with an Rt of $18.2 \mathrm{~min}$. No strong increase of YTXs in the tissue was observed directly after start of the inoculation. The amount of all detected YTXs increased significantly after 16 days (Fig. 1, Table 1). We stopped feeding at day 16. After a break of 4 days, the concentration of the YTXs did not decrease. Subsequently, the levels of YTX, 45-OH

TABLE 2.

Concentration of YTXs in C. gigas in microgram YTX equivalents per kilogram wet weight.

\begin{tabular}{|c|c|c|c|c|c|c|}
\hline Transition & $\begin{array}{c}m / z 1,141.5> \\
1,061.5\end{array}$ & $\begin{array}{c}m / z 1,157.5> \\
1,077.5\end{array}$ & $\begin{array}{c}m / z 1,173.5> \\
1,093.5\end{array}$ & $\begin{array}{c}m / z 1,189.5> \\
1,089.5\end{array}$ & $\begin{array}{c}m / z 1,047.5> \\
967.5\end{array}$ & $\begin{array}{c}m / z, 1,191.5> \\
1,111.5\end{array}$ \\
\hline $\begin{array}{l}\text { Retention time } \\
\quad(\min )\end{array}$ & 21.3 & 19.4 & 18.5 & 18.7 & 19.5 & 18.2 \\
\hline Time (day) & & & concentra & g/kg BW) & & \\
\hline 2 & 23.00 & 32.96 & 20.77 & n.d. & 5.55 & 4.06 \\
\hline 4 & 26.39 & 60.32 & 25.87 & n.d. & 10.04 & 4.54 \\
\hline 6 & 23.66 & 20.23 & 16.93 & n.d. & 9.72 & 5.53 \\
\hline 8 & 48.13 & 28.48 & 31.11 & 1.86 & 15.78 & 5.21 \\
\hline 10 & 140.11 & 130.16 & 67.32 & 8.28 & 47.75 & 13.94 \\
\hline 12 & 58.69 & 58.31 & 45.17 & 3.38 & 28.85 & 8.48 \\
\hline 14 & 16.07 & 13.66 & 14.95 & 2.35 & 46.51 & 4.88 \\
\hline 16 & 120.25 & 224.55 & 49.50 & 11.92 & 72.84 & 25.49 \\
\hline 22 & 18.11 & 10.34 & 15.66 & 2.19 & 19.88 & 4.99 \\
\hline 24 & 18.40 & 6.67 & 27.37 & 2.29 & 46.95 & 7.89 \\
\hline 26 & 19.48 & 11.81 & 23.19 & 2.58 & 65.67 & 9.16 \\
\hline 28 & 40.79 & 30.22 & 19.23 & 4.21 & 79.18 & 10.20 \\
\hline 30 & 15.63 & 9.61 & n.d & 1.70 & 33.77 & 3.64 \\
\hline 32 & 25.57 & 8.37 & 4.47 & n.d & 102.18 & 4.35 \\
\hline 34 & 21.92 & 11.12 & 11.16 & 3.10 & 142.84 & 7.22 \\
\hline 36 & 2.89 & n.d. & n.d. & n.d. & n.d. & n.d. \\
\hline
\end{tabular}

n.d., not detected. 
YTX, and $\mathrm{COOH}$ YTX declined during the detoxification period, whereas the concentration of $45-\mathrm{OH}-\mathrm{COOH}$ YTX remained in the same range.

C. gigas showed a different profile of YTXs compared with M. edulis. YTX $m / z 1,141.5>1,61.5,45-\mathrm{OH}$ YTX $m / z$ 1,157.5 > 1,077.5, and 45-OH-COOH YTX $m / z$ 1,189.8 > 1,109.5 were also present, and 45-OH-COOH YTX was detectable in low amounts (Table 2, Fig. 2); however, COOH YTX $m / z$ 1,173.5 > 1,093.5 was not found at an Rt of $18.2 \mathrm{~min}$, but 2 signals with the same multireaction monitoring characteristics (same transition) were observed at an Rt of $18.5 \mathrm{~min}$ and $18.9 \mathrm{~min}$, respectively. After the break of 4 days, the dominant YTX analogues (YTX and 45$\mathrm{OH}$ YTX) were almost degraded/eliminated. Approximately $15 \%$ YTX and less than 5\% 45-OH YTX remained. Hence, the detoxification of these YTXs occurs very fast in C. gigas.

In addition, we found 2 YTX analogues with the typical loss of the sulfo group ( $80 \mathrm{amu}$ ) in both bivalves (YTX analogues $m / z 1,047.5>967.5$ with an Rt of $19.5 \mathrm{~min}$ and $m / z 1,191.5>$ 1,111.5 with an Rt of $18.2 \mathrm{~min}$ ). However, these YTXs were present in M. edulis as minor components, and less amounts of the latter (YTXs $m / z 1,191.5>1,111.5$ ) were accumulated in C. gigas. Interestingly, the concentration of the putative YTXs with $m / z 1,047.5>967.5$ increased over both time periods.

\section{DISCUSSION}

In the current study, we confirmed the results of former field investigations about the metabolism of YTX in blue mussel ( $M$. edulis; Fig. 3). New data are presented concerning accumulation and detoxification in the Pacific oyster ( $C$. gigas). Oysters showed a different response to toxification by YTX, and a possible metabolic pathway - especially in C. gigas - is under discussion.

Aasen et al. (2005) reported 45-OHYTX (MW, 1,058 Da), COOH YTX (MW, 1,174 Da), and the putative 45-OH-COOH YTX (MW, 1,190 Da) as the dominant YTX analogue in $M$. edulis. The metabolism of YTX to 45-OH YTX takes place relatively rapid in the shellfish tissue; a half-life time of YTXs of 20-24 days was observed. Furthermore, COOH YTX was more abundant than YTX and 45-OH YTX. Consequently, it was concluded that detoxification of $\mathrm{COOH}$ YTX occurs more slowly than YTX and 45-OH YTX (Aasen et al. 2005, Samdal et al. 2005). All YTXs mentioned previously were detectable in M. edulis in low concentrations until day 14. These results are in accordance with former studies (MacKenzie et al. 1998, MacKenzie et al. 2001, Koike et al. 2006). In our study, YTX was the dominant analogue only over a short time period; however, after 4 days, the concentration of $\mathrm{COOH}$ YTX was higher than the concentration of YTX in M. edulis. In addition, 45-OH-COOH YTX was long-lasting in the tissue of M. edulis, and the concentration of 45-OH-COOH YTX measured at the last day of sampling was not lower than the concentration present at the beginning of the detoxification period. This result confirms the assumption that 45-OH-COOH YTX originates from 45-OH YTX (Aasen et al. 2005) and/or COOH YTX (Table 1, Figs. 1A and 3A). The concentration of YTXs in $M$. edulis and C.gigas was low in comparison with the concentration

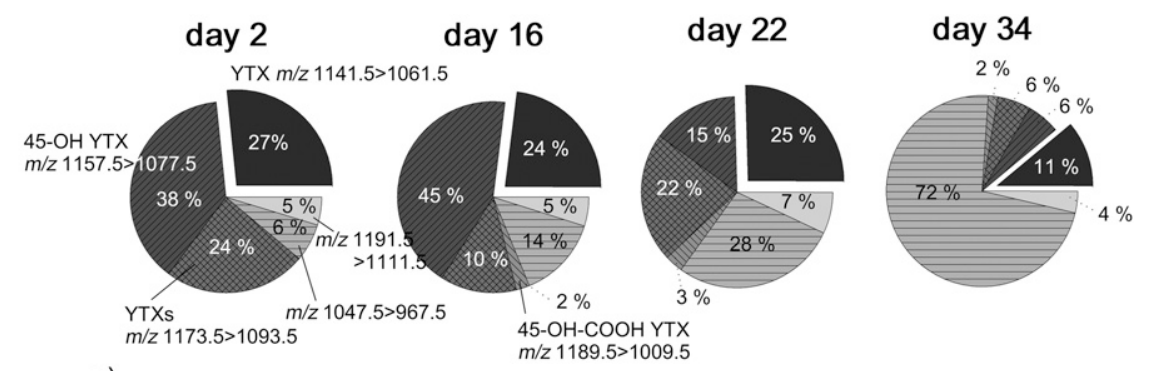

a)

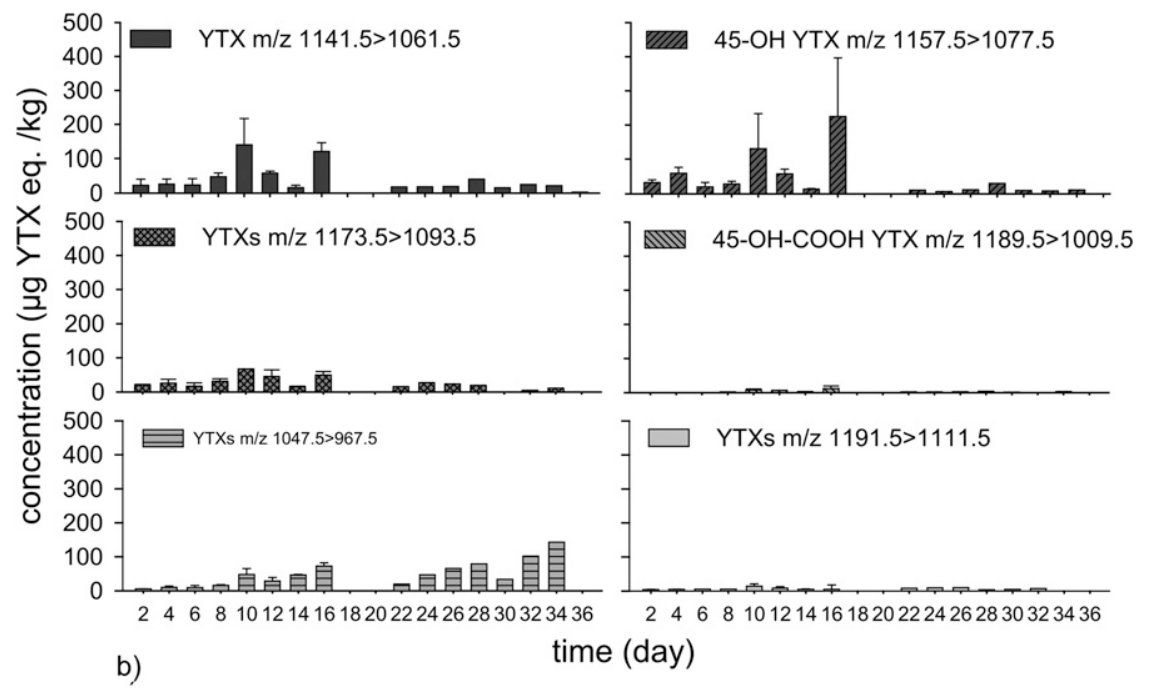

Figure 2. (A, B) Concentration of YTXs in C. gigas as a percentage (A) and as a total concentration in micrograms YTX equivalents per kilogram wet weight (B). Analogues in YTX equivalents $(m / z 1,173.5>1,093.5)$. Only 1 of the 2 YTX analogues with an Rt of 18.7 min is shown. For all other retention times, see Figure 1. 

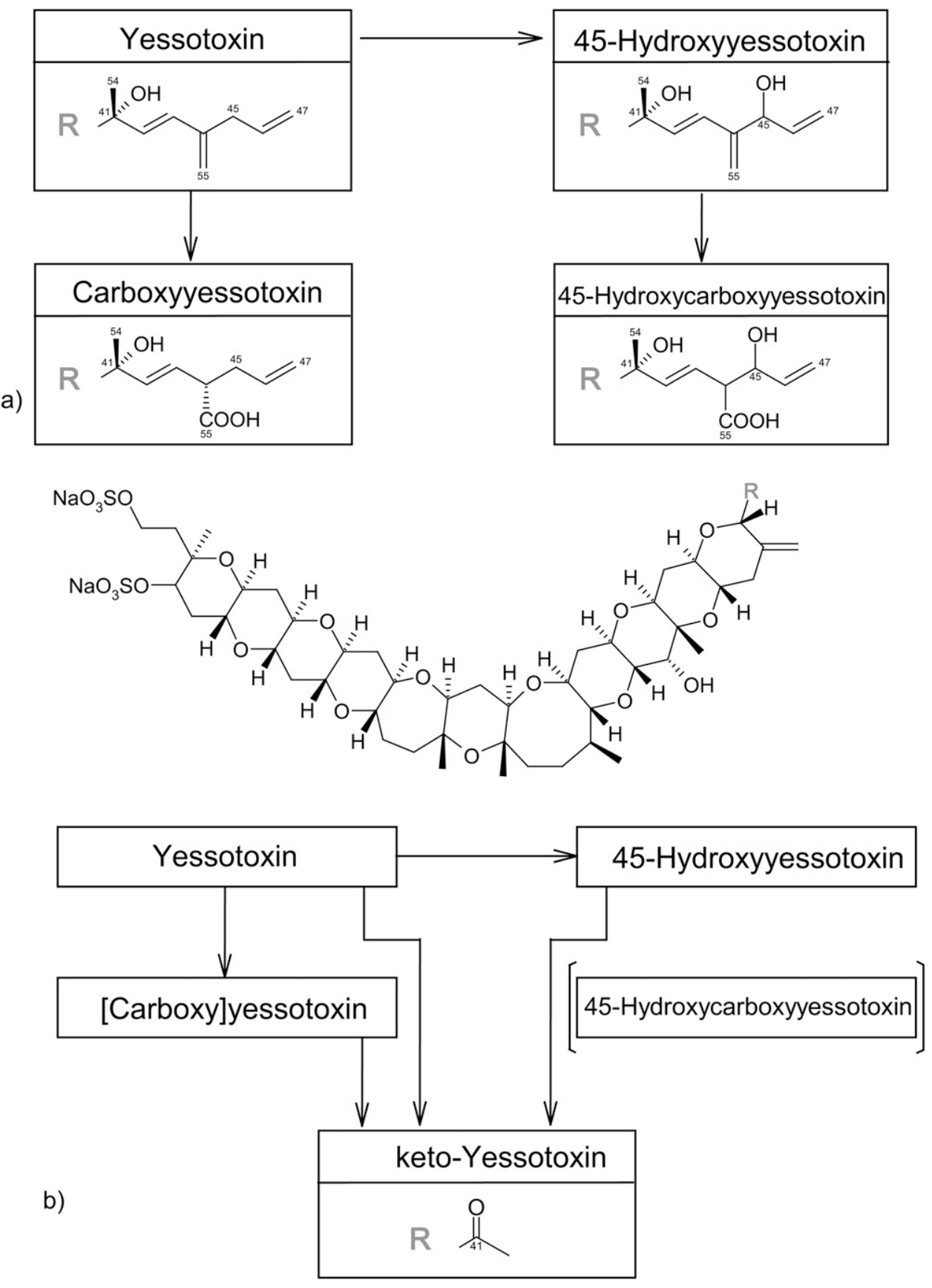

Figure 3. (A) Metabolism of YTX in M. edulis (Aasen et al. 2002), modified. (B) Putative metabolism of YTX in C. gigas.

of YTXs reported in the literature. Potentially, the lower concentrations measured during our experiments were caused by the relative low concentrations of YTXs in the culture of $P$. reticulatum $(5.58 \pm 1.66 \mathrm{pg} /$ cell $)$ and were associated with a smaller amount of cells per liter in comparison with natural blooms. Several authors stated that the concentration of YTX in $P$. reticulatum ranged from $0.9-79 \mathrm{pg} /$ cell, whereas the toxin profile of the dinoflagellate can differ (MacKenzie et al. 2002, Paz et al. 2004, Samdal et al. 2006, Paz et al. 2007).

As reported by Aasen et al. (2005), a reason for the variation of the data concerning concentrations of YTXs obtained by LC-MS/MS and ELISA analyses could be that additional analogues are present in the mussel samples. In this context, 2 YTX analogues $(m / z 1,047$ and $m / z 1,191)$ could be detected, but the exact chemical structure is not elucidated so far. We assume that $m / z$ 1,047 could be a keto YTX (heptanor-41-oxo YTX; 40epi-keto YTX or keto YTX-enone) with an MW of 1,048 Da.

Both bivalve species fed on the same dinoflagellate culture, yet differences in the toxin profiles were observed. Apparently, accumulation and detoxification of YTXs in C. gigas is faster than in $M$. edulis. Furthermore, $C$. gigas did not produce/ accumulate $\mathrm{COOH}$ YTX, and 45-OH-COOH YTX and a substance with $m / z 1191$ were present only in small amounts. The identification of the peaks with $\mathrm{COOH}$ YTX-like transitions is 
foreseen for later analyses; however, there is evidence that the structure is probably related to stereo-isomers of COOH YTX. Surprisingly, the concentration of the YTX analogue with $m / z$ 1,047 increased during the detoxification period. Potentially, this substance is formed at the end of the detoxification process (Table 2, Fig. 3B).

The metabolism in the greenshell mussel (Perna canaliculus) seems to be similar to the metabolism in $M$. edulis, albeit the process of metabolism is somewhat slower (half-life of 49 days). LC-MS/MS analyses by MacKenzie et al. (2002) demonstrated the presence of YTX and 45-OH-YTX in the greenshell mussel. Interestingly, the authors found YTX also analogues with 1,173 and 1,189. These more polar metabolites of YTX gave the characteristic loss of daughter ions (80 amu) by fragmentation in the mass spectrometer. MacKenzie et al. (2002) supposed the YTX substances are COOH YTX and $\mathrm{OH}-\mathrm{COOH}$ YTX. Given at the results by Aasen et al. (2005) and our data, this assumption is supported.

Independent of similarities in profiles of YTXs in the mussels M. edulis and P. canaliculus, more YTXs have been detected in the Mediterranean mussel (Mytilus galloprovincialis), which is more closely related to M. edulis (Ciminiello et al. 2000). These authors reported on the accumulation of ATX and homo YTX besides YTX, OH YTX, and COOH YTX in M. galloprovincialis, whereas Morton et al. (2007) detected YTX, OH YTX, and homo YTX in M. galloprovincialis. Finch et al. (2005) reported the presence of YTX, OH YTX, $\mathrm{COOH}$, and di-OH YTX in all mussel species under investigation with YTX as the main component in M. edulis and P. canaliculus (in every case more than 60\%), and with COOH YTX (40\%) and YTX (32\%) as main components in M. galloprovincialis.

To date, knowledge concerning the relationship between YTX-producing dinoflagellates and shellfish with respect to the resulting toxin profile is incomplete. In this study, the YTX producer $P$. reticulatum forms mainly YTX, together with very low amounts of YTX analogues. Therefore, we assume that YTX is preferentially metabolized in the shellfish tissue after uptake of $P$. reticulatum. On the other hand, it cannot be discounted that the putative keto YTX, which was present in the culture in low amounts, was accumulated by C. gigas, and consequently the concentration of this YTX analogue increased in the tissue of $C$. gigas also in absence of P. reticulatum.

Currently, the mouse bioassay (MBA) is the standard method for testing shellfish with regard to lipophilic marine biotoxins in Europe (European Commission 2005); however, other methods (e.g., chromatographic methods and bioassays) could be applied alternatively or as a supplement. Yet, differences between results obtained by application of ELISA, MBA, or HPLC-MS methods were observed (Miles et al. 2005a, Samdal et al. 2005). One reason is that, in contrast to chromatographic methods, the total toxin concentration is analyzed by application of ELISA and MBA. Currently, regulatory limits exist for YTX, OH YTX, homo YTX, and OH-homo YTX (European Food Safety Authority 2008). However, the potential presence of about 100 YTX analogues in different shellfish species is problematic with regard to seafood safety, because their toxicity seems to be different. Because YTXs and more toxic lipophilic marine biotoxins, DSP toxins (e.g., okadaic acid and dinophysistoxins) cause similar reactions when injected intraperitoneally in mice, other extraction methods were established for their differentiation, but it is also evident that some desulfo YTXs were coextracted with okadaic acid and dinophysistoxins (Ciminiello et al. 2007).

In summary, the presence of YTX, OH YTX, COOH YTX, and $\mathrm{OH}-\mathrm{COOH} \mathrm{YTX}$ in $M$. edulis fed with $P$. reticulatum from the North Sea confirmed the results of studies by Aasen et al. (2005). The exact structure of the detected YTX analogues with $m / z 1,047.5>967.5$ and $m / z 1,191.5>1,111.1$ should be elucidated in the future. As a result of this first study regarding accumulation and metabolism of YTXs in C. gigas, it was obvious that differences exist between mussels (M. edulis) and oysters ( $C$. gigas) concerning the toxin profiles and the rates of detoxification. In comparison with M. edulis, YTX accumulates faster and is more quickly eliminated in C. gigas. Consequently, our investigations indicate that accumulation and metabolism of YTXs in different species depend on the toxin profile of the YTX-producing dinoflagellates as well as on the filter feeders.

\section{LITERATURE CITED}

Aasen, J., I. Samdal, C. O. Miles, E. Dahl, L. Briggs \& T. Aune. 2005. Yessotoxins in Norwegian blue mussels (Mytilus edulis): uptake from Protoceratium reticulatum, metabolism and depuration. Toxicon 45:265-272.

Alfonso, A., L. de la Rosa, M. R. Vieytes, T. Yasumoto \& L. M. Botana. 2003. Yessotoxin, a novel phytotoxin, activates phosphodiesterase activity: effect of yessotoxin on cAMP levels in human lymphocytes. Biochem. Pharmacol. 65:193-208.

Aune, T., R. Sorby, T. Yasumoto, H. Ramstad \& T. Landsverk. 2002. Comparison of oral and intraperitoneal toxicity of yessotoxins towards mice. Toxicon 40:77-82.

Blanco, J., M. Fenández, A. Míguez \& Á. Morono. 1999. Okadaic acid depuration in the mussel Mytilus galloprovincialis: one- and twocompartment models and the effect of environmental conditions. Mar. Ecol. Prog. Ser. 176:153-163.

Callegari, F. \& G. P. Rossini. 2008. Yessotoxin inhibits the complete degradation of E-cadherin. Toxicology 244:133-144.

Ciminiello, P., C. Dell'Aversano, E. Fattorusso, M. Forino, L. Grauso, S. G. Magno, R. Poletti \& L. Tartaglione. 2007. Desulfoyessotoxins from Adriatic mussels: a new problem for Seafood safety control. Chem. Res. Toxicol. 20:95-98.
Ciminiello, P., C. Dell'Aversano, E. Fattorusso, M. Forino, S. Magno, F. Guerrini, R. Pistocchi \& L. Boni. 2003. Complex yessotoxins profile in Protoceratium reticulatum from north-western Adriatic Sea revealed by LC-MS analysis. Toxicon 42:7-14.

Ciminiello, P., E. Fattorusso, M. Forino, S. Magno, R. Poletti \& R. Viviani. 1998. Isolation of adriatoxin, a new analogue of yessotoxin from mussels of the Adriatic sea. Tetrahedron Lett. 39:88978900.

Ciminiello, P., E. Fattorusso, M. Forino, R. Poletti, M. Satake, R. Viviani \& T. Yasumoto. 1997. Yessotoxin in mussels of the northern Adriatic Sea. Toxicon 35:177-183.

Ciminiello, P., E. Fattorusso, M. Forino, R. Poletti \& R. Viviani. 2000. A new analogue of yessotoxin, carboxyyessotoxin, isolated from Adriatic Sea mussels. Eur. J. Org. Chem. 2:291-295.

Dechraoui, M.- Y., J. Naar, S. Pauillac \& A.-M. Legrand. 1999. Ciguatoxin and brevetoxins, neurotoxic polyether compound active on sodium channels. Toxicon 37:125-143.

De la Rosa, L. A., A. Alfonso, N. Vilarino, M. R. Vieytes \& L. M. Botana. 2001. Modulation of cytosolic calcium levels of human lymphocytes by yessotoxin, a novel marine phycotoxin. Biochem. Pharmacol. 61:827-833. 
Denac, H., M. Mevissen \& G. Scholtysik. 2000. Structure, function and pharmacology of voltage-gated sodium channel. Naunyn Schmiedebergs Arch. Pharmacol. 362:453-479.

Draisci, R., E. Ferretti, L. Palleschi, C. Marchiafava, R. Poletti, A. Milandri, A. Ceredi \& M. Pompei. 1999. High levels of yessotoxin in mussels and presence of yessotoxin and homoyessotoxin in dinoflagellates of the Adriatic Sea. Toxicon 37:1187-1193.

European Commission. 2002. Commission decision of March 15, 2002, laying down detailed rules for the implementation of Council Directive 91/492/EEC with regard to the maximum levels and the methods of analysis of certain marine biotoxins in bivalve molluscs, echinoderms, tunicates, and marine gastropods. (2002/225/EC). OJ L75:62-64.

European Commission. 2005. Commission regulation (EC) no. 2074/ 2005 of December 5, 2005, laying down implementing measures for certain products under regulation (EC) no. 853/2004 of the European Parliament and of the Council and for the Organization of Official Controls under Regulation (EC) no. 854/2004 of the European Parliament and of the Council and Regulation (EC) no. 882/2004 of the European Parliament and of the Council, derogating from Regulation (EC) no. 852/2004 of the European Parliament and of the Council and amending Regulation (EC) nos. 853/2004 and 854/2004. OJ L 338:27-59.

European Food Safety Authority. 2008. Opinion of the Scientific Panel on Contaminants in the Food Chain on a request from the European Commission on Marine Biotoxins in Shellfish-Yessotoxin Group. EFSA J. 907:1-62.

Finch, S. C., A. L. Wilkins, A. D. Hawkes, J. J. Dwayne, A. L. MacKenzie, V. Beuzenberg, M. A. Quilliam, C. D. Olsen, I. A. Samdal, J. Aasen, A. I. Selwood, J. M. Cooney, M. Sandvik \& C. O. Miles. 2005. Isolation and identification of (44-R,S)-44,55-dihydroxyyessotoxin from Protoceratium reticulatum, and its occurrence in extracts of shellfish from New Zealand, Norway and Canada. Toxicon 46:160-170.

Guillard, R. R. 1975. Culture of phytoplankton for feeding marine invertebrates. In: W. L. Smith \& M. H. Chanley, editors. Culture of marine invertebrate animals. New York: Plenum Press. pp. 29-60.

Honkanen, R. E., B. A. Codispodi, K. Tse \& A. L. Boyton. 1994. Characterisation of natural toxins with inhibitory activity against serine/threonine protein phosphatase. Toxicon 32:339-350.

Inoue, M., M. Hirama, M. Satake, K. Sugiyama \& T. Yasumoto. 2003. Inhibition of brevetoxin binding to the voltage-gated sodium channel by gambierol and gambieric acid-A. Toxicon 41:469-474.

Koike, K., Y. Horie, T. Suzuki, A. Kobiyama, K. Kurihara, K. Takagi, S.- N. Kaka \& Y. Oshima. 2006. Protoceratium reticulatum in northern Japan: environmental factors associated with seasonal occurrence and related contamination of yessotoxin in scallops. $J$. Plankton Res. 28:103-112.

Krock, B., T. Alpermann, U. Tillmann, G. C. Pitcher \& A. D. Cembella. 2006. Yessotoxin (YTX) profiles from cultures and plankton samples of the marine dinoflagellates Protoceratium reticulatum and Gonyaulax spinifera. In: Ø. Moestrup, editor. Proceedings of the 12th International Conference on Harmful Algae, Copenhagen, Denmark, 4-8 September 2006. Copenhagen: International Society for the Study of Harmful Algae (ISSHA) and the Intergovernmental Oceanographic Commission (IOC of UNESCO). pp. 303-305.

MacKenzie, L., P. Holland, P. McNabb, V. Beuzenberg, A. Selwood \& T. Suzuki. 2002. Complex toxin profiles in phytoplankton and greenshell mussels (Perna canaliculus), revealed by LC-MS/MS analysis. Toxicon 40:1321-1330.

MacKenzie, L., T. Suzuki \& J. Adamson. 2001. Elimination and differential transformation of yessotoxin by the greenshell mussel Perna canaliculus and blue shell mussel Mytilus galloprovincialis. In: G. M. Hallegraeff, S. I. Blackburn C. J. Bolch \& R. J. Lewis, editors. Harmful algal blooms. Paris: Intergovernmental Oceanographic Commission of UNESCO. pp. 371-374.

MacKenzie, L. \& P. Trumann \& T. Yasumoto. 1998. Dinoflagellate blooms and associated DSP-toxicity in shellfish in New Zealand. In:
B. Reguera, J. Blanco, M. L. Fernández \& T. Wyatt, editors Harmful algae. Paris: Intergovernmental Oceanographic Commission of UNESCO. pp. 74-77.

Miles, C. O., I. A. Samdal, J. A. Aasen, D. J. Jensen, M. A. Quilliam, D. Petersen, L. M. Briggs, A. L. Wilkins, F. Rise, J. M. Cooney \& J. A MacKenzie. 2005a. Evidence for numerous analogs of yessotoxin in Protoceratium reticulatum. Harmful Algae 4:1075-1091.

Miles, C. O., A. L. Wilkins, A. D. Hawkes, A. I. Selwood, D. J. Jensen, J. M. Cooney, V. Beuzeberg \& A. L. MacKenzie. 2006a. Identification of 45-hydroxy-46,47-dinoryessotoxin, 44-oxo-45,46,47trinoryessotoxin, and 9-methyl-42,43,44,45,46,47,55-heptanor38-en-41-oxoyessotoxin, and partial characterization of some minor yessotoxins, from Protoceratium reticulatum. Toxicon 47: 229-240.

Miles, C. O., A. L. Wilkins, A. D. Hawkes, A. I. Selwoold, D. J. Jensen, R. Munday, J. M. Cooney \& V. Beuzenberg. 2005b. Polyhydroxylated amide analogs of yessotoxin from Protoceratium reticulatum. Toxicon 45:61-71.

Miles, C. O., A. L. Wilkins, D. J. Jensen, J. M. Cooney, M. A. Quilliam, J. Aasen \& A. L. MacKenzie. 2004. Isolation of 41a-homoyessotoxin and the identification of 9-methyl-4lahomoyessotoxin and nor-ring A-yessotoxin from Protoceratium reticulatum. Chem. Res. Toxicol. 17:1414-1422.

Miles, C. O., A. L. Wilkins, A. I. Selwood, A. D. Hawkes, D. J. Jensen, J. M. Cooney, V. Beuzenberg \& A. L. MacKenzie. 2006b. Isolation of yessotoxin 32-O-[ $\beta$-L-arabinofuranosyl- $\left(5^{\prime} \rightarrow 1^{\prime \prime}\right)-\beta$-L-arabinofuranoside] from Protoceratium reticulatum. Toxicon 47:510-516.

Morton, S. L., A. Vershinin, T. Leighfeld, L. Smith \& M. Quilliam. 2007. Identification of yessotoxin in mussels from the Caucasian Black Sea Coast of the Russian Federation. Toxicon 50:581-584.

Murata, M., M. Kumakai, J. Soo Lee \& T. Yasumoto. 1987. Isolation and structure of yessotoxin, a novel polyether compound implicated in diarrhetic shellfish poisoning. Tetrahedron Lett. 28:5869-5872.

Naar, J., J. Leann, A. Lenzi, A. G. Abbot, H. Jacocks, D. Gannon, M. Henry, R. Pierce, D. Baden, J. Wolny \& J. Landsberg. 2007. Brevetoxins, like ciguatoxins, are potent ichthyotoxic neurotoxins that accumulate in fish. Toxicon 50:707-723.

Ogino, H., M. Kumagai \& T. Yasumoto. 1997. Toxicologic evaluation of yessotoxin. Nat. Toxins 5:255-259.

Paz, B., A. H. Daranas, M. Norte, P. Riobó, J. M. Franco \& J. J. Fernández. 2008. Yessotoxins, a group of marine polyether toxins: an overview. Marine Drugs 6:73-102.

Paz, B., P. Riobó, M. L. Fernández, S. Fraga \& J. M. Franco. 2004. Production and release of yessotoxins by the dinoflagellates Protoceratium reticulatum and Lingulodinium polyedrum in culture. Toxicon 44:251-258

Paz, B., P. Riobó, I. Ramilo \& J. M. Franco. 2007. Yessotoxins profile in strains of Protoceratium reticulatum from Spain and USA. Toxicon 50:1-17.

Pazos, M. A., A. Alfonso, M. R. Vieytes, T. Yasumoto \& L. M. Botana. 2005. Kinetic analysis of the interaction between yessotoxin and analogues and immobilized phosphodiesterases using a resonant mirror optical biosensor. Chem. Res. Toxicol. 18:1155-1160.

Pérez-Gómez, A., A. Ferrero-Gutierrez, A. Novelli, J. M. Franco, B. Paz \& M. T. Fernández-Sánchez. 2006. Potent neurotoxic action of the shellfish biotoxin yessotoxin on cultured cerebellar neurons. Toxicol. Sci. 90:168-177.

Ramstad, H., P. Hovgaard, T. Yasumoto, S. Larsen \& T. Aune. 2001. Monthly variations in diarrhetic toxins and yessotoxin in shellfish from coast to the inner part of the Sognefjord, Norway. Toxicon 39:1035-1043.

Rhodes, L., P. McNabb, M. De Salas, V. Briggs, V. Beuzenberg \& M. Gladstone. 2006. Yessotoxin production by Gonyaulax spinifera. Harmful Algae 5:148-155.

Riccardi, M., F. Guerrini, F. Roncarati, A. Milandri, M. Gangini, S. Rigozzi, E. Riccardi, A. Ceredi, P. Ciminiello, C. Dell'Aversano, E. Fattorusso, M. Forino, L. Tartaglione \& R. Pistocchi. 2009. 
Gonyaulax spinifera from the Adriatic Sea: toxin production and phylogenetic analysis. Harmful Algae 8:279-290.

Samdal, I. A., J. Aasen, L. R. Briggs, E. Dahl \& C. O. Miles. 2005. Comparison of ELISA and LC-MS analyses for yessotoxins in blue mussels (Mytilus edulis). Toxicon 47:7-15.

Samdal, I. A., L. J. Naustvoll, C. D. Olseng, L. R. Briggs \& C. O. Miles. 2006. Use of ELISA to identify Protoceratium reticulatum as a source of yessotoxin in Norway. Toxicon 44:75-82.

Samdal, I. A., C. D. Olseng, M. Sandvik, C. O. Miles, L. R. Briggs, T. Torgersen \& D. J. Jensen. 2004b. Profile of yessotoxin analogues in a Norwegian strain of Protoceratium reticulatum. In: Henshilwood, K., Deegan, B., McMahon, T., Cusack, C., Keaveney, S., Silke, J., O'Cinneide, M., Lyons, D., Hess, P., editors, Proceedings of the Fifth International Conference on Molluscan Shellfish Safety, June 14-18, 2004, Galway, Ireland. pp. 242-247.

Satake, M., T. Ichimura, K. Sekiguchi, S. Yoshimatsu \& Y. Oshima. 1999. Confirmation of yessotoxin and 45,46,47-trinoryessotoxin production by Protoceratium reticulatum collected in Japan. Nat. Toxins 7:147-150.

Satake, M., L. MacKenzie \& T. Yasumoto. 1997. Identification of Protoceratium reticulatum as the biogenetic origin of yessotoxin. Nat. Toxins 5:164-167.

Souto, M. L., J. J. Fernández, J. M. Franco, B. Paz, L. V. Gil \& M. Norte. 2005. Glycoyessotoxin A, a new yessotoxin derivative from cultures of Protoceratium reticulatum. J. Nat. Prod. 68:420422.
Suzuki, T., Y. Horie, K. Koike, M. Satake, Y. Oshima, M. Iwataki \& Y. Sadaaki. 2007. Yessotoxin analogues in several strains of Protoceratium reticulatum in Japan determined by liquid chromatography-hybrid triple quadrupole/linear ion trap mass spectrometry. J. Chrom. A 1142: $172-177$.

Takai, A. \& G. Mieskes. 1991. Inhibitory effect of okadaic acid on the p-nitrophenyl phosphate phosphatase activity of protein phosphatases. Biochem. J. 275:233-239.

Takai, A., M. Murata, K. Torigoe, M. Isobe, G. Mieskes \& T. Yasumoto. 1992. Inhibitory effect of okadaic acid derivatives on protein phosphatases. Biochem. J. 284:539-544.

Tubaro, A., L. Sidari, R. Della Loggia \& T. Yasumoto. 1998. Occurrence of homoyessotoxin in phytoplankton and mussels from Northern Adriatic Sea. In: B. Reguera, J. Blanco, M. L. Fernandez \& T. Wyatt, editors. Harmful algae. Santiago de Compostela: Xunta de Galicia and Intergovernmental Oceanographic Commission of UNESCO. pp. 470-472.

Tubaro, A., S. Sosaa, G. Altinier, M. R. Soranzo, M. Satake, R. Della Loggia \& T. Yasumoto. 2004. Short-term oral toxicity of homoyessotoxins, yessotoxin and okadaic acid in mice. Toxicon 43:439-445.

Windust, A. J., J. L. C. Wright \& J. L. McLachlan. 1996. The effects of the diarrhetic shellfish poisoning toxins, okadaic acid and dinophysistoxin-1, on the growth of microalgae. Mar. Biol. 126:19-25.

Yasumoto, T. \& A. Takizawa. 1997. Fluorometric measurement of yessotoxins in shellfish by high-pressure liquid chromatography. Biosci. Biotechnol. Biochem. 61:1775-1777. 